\title{
The Metaphors of Quests, Labyrinths and the Dance of Kali in Christopher Koch's The Year of Living Dangerously
}

\author{
Sathyabhama Daly
}

University of Queensland

Ovid's myth of the Cretan labyrinth, constructed by Daedalus to hide the Minotaur, the monster that is a result of Pasiphae's lust ${ }_{\underline{1}}$, and Dante's labyrinth of Hell, in The Inferno, are literary allusions that conjure images of imprisonment and moral dilemma. In this paper, I explore the metaphor of the labyrinth in The Year of Living Dangerously (YLD) and the way in which Koch integrates this metaphor with Christian, Hindu and Buddhist myths so as to engage with the cultural divide that continues to influence Christian and non-Christian worldviews. The labyrinth metaphor emerges through the imagery of the novel which focuses on caves, shadows, circuitous paths, entrapment, and moral choices. In the novel, the metaphor of the labyrinth is conveyed through the underworld imagery of Indonesian society and through the Wayang Bar, the citadel of the journalists trapped in a world of political intrigue and of good and evil. Metaphorically evoking the medieval concept of the world as a perilous maze, Koch uses the labyrinth as a way of imaging the search for the sacred in contemporary society . $_{\text {. }}$

In The Year of Living Dangerously, which is about the political turmoil in Indonesia in 1965 under the rule of Sukarno, Koch's vision of spiritual desacralisation emerges through the figure of Kali, since, according to Hindu doctrine, the world is in the phase of "Kãli-yuga", the phase of spiritual decadence, 'that is 'the dark era,' the period of total confusion and utter spiritual decadence, the final stage in the completion of a cosmic cycle" (Eliade, Patterns in Comparative Religion 182). The etymology of the word "Kali" is derived from the Sanskrit root word for "Kala" and these words were associated with the goddess who was to become the symbol of time $\underline{3}_{\underline{3}}$. In Hindu mythology, Kali retains her power as a demonic force, and it is this terrifying aspect that Koch utilises so effectively in The Year of Living Dangerously ${ }_{4}$. He does not use Kali as a sacred myth; she is rather a useful metaphor, since her Dionysiac energy complements his engagement with Manichaeism, and with the metaphor of human beings trapped within the wheel of life: the endless cycle of suffering, death and rebirth. 
In The Year of Living Dangerously, Koch continues his obsessive theme of Plato's Cave, of human beings trapped within a world of dream and illusion, by magnifying it further through the framework of the traditional Indonesian shadow play, the wayang kulit, whereby all the characters are puppets manipulated by a dalang, the puppet-master who plays with his creations $_{\underline{5}}$. The image of the labyrinth and of souls trapped within it is present in the description of the Wayang Bar: "Coming into this circular chamber, you stepped from the flat blaze of the equator into a permanent half-dark, to which air-conditioning added a Scandinavian cold" ((YLD 3). The darkness of the chamber and the "Scandinavian cold" provides a retreat from the heat and humidity-the inferno that is Indonesia. The idea of being trapped in a labyrinth is intensified further through the description of the dim light of the "fat red candles" and the "ring of electric lamps", that casts eerie shadows of the Javanese puppets on the wall (YLD 3-4). In effect, the actors, the lighting and the scene are set for another shadow play - the struggle between the forces of light and darkness. Koch manipulates the basic structure of the wayang with its mythopoeic framework which, although it originates in Indonesia, is based on Hindu myths from India. The author takes on the role of the dalang in the wayang kulit performance ${ }_{6}$. As such, the wayang shadows provide Koch with metaphors for illusion and reality and of entrapment in the otherworld of myth.

Within the concept of the labyrinth in The Year of Living Dangerously is contained the journey of the soul in search of enlightenment. The Grail Quest became established as a literary motif in the thirteenth century; it concerns the spiritual journey of a chosen few, the elect, who are successful in their search for Christ, symbolised by the Grail. The search for the Holy Grail is a symbol of the archetypal search for truth ${ }_{7}$. In the Grail legend it is the quest that becomes the central motif, and the literary pattern is of a pilgrim, a dark journey, and obstacles that must be overcome if the pilgrim is to be successful. In The Year of Living Dangerously, Billy Kwan's and Hamilton's journeys follow this pattern of the quest: "the blight on the land", the dark night of the soul, the temptations by sirens who threaten the pilgrim's spiritual journey, and the completion of the quest which is symbolised by the Garden, which the pilgrim enters "through a Wall of Flame at the end of a dark Wood" (Locke 3) ${ }_{8}$. The quest is a particularly appropriate motif since it expresses the view that contemporary Australian society is spiritually decadent and in need of guidance. The spiritual fable masks the didactic moral of the novel. Billy Kwan's and Hamilton's spiritual journeys mimic the trials and tribulations of the knights of the Holy Grail, whose success is dependent 
on the Christian concept of grace, and each knight's desire for spiritual truth. The Christian concept of grace is evident in Billy Kwan's moral obligation to the Indonesian people, where he is driven by a spiritual desire to alleviate the suffering and poverty he encounters in a blighted land. This Christian concept of grace in the novel is interlaced with the Hindu doctrine of dharma, or moral duty, with the Christian concept of free-will in conflict with the Hindu concept of destiny. Billy's fate takes on the dual perspective of free-will versus destiny: his spiritual duty spurs him on to action, the quest itself resulting in his death. In the novel the quest and the labyrinth are the motifs used to describe the spiritual journeys undertaken by Billy Kwan and Hamilton.

Koch reworks the Grail legend into the text by presenting Billy and Hamilton as Galahad and Gawain, the two "knights" elected to undertake the spiritual quest. The Wayang Club becomes the court which is presided over by "Sir" Wally, and the other journalists represent those whose spiritual blindness condemn them to the Hindu destiny of being caught in the wheel of life. The narrator makes oblique references to the Grail quest by alerting the reader to the footnote reference in Billy's dossier entry, linking Billy and Hamilton to the ancient dwarf-figure Pelles of the Grail legend (YLD 117). Hamilton is linked to the Grail hero Gawain through mocking references made by Wally, who refers to the relationship between Hamilton and Billy as that of "Sir Guy and the Black Dwarf" (YLD 44).

Quests and labyrinths have much in common, since they embody the concept of a journey in pursuit of a prized goal. The journey itself involves making moral choices, overcoming difficult obstacles, and perseverance in the face of adversity. The concept of being guided by an external force is also built into the narrative of the quest. Incorporated within the structure of most labyrinths is the concept that the artistry of the maze is controlled by a Daedalian figure ${ }_{9}$. Koch invokes the concept of a god-like or Daedalian figure controlling the artistry of the maze, by using as metaphor the wayang symbolism of the narrator as a dalang or god who manipulates his puppets. In the labyrinthine world of The Year of Living Dangerously, the maze-maker's role is dual, with the artist as shaman embodying the divinity of Christ, as well as the diabolic aspect of Kali.

In the medieval period, there were two models of the labyrinth: the unicursal and the multicursal. The unicursal model has a single circuitous path which inevitably leads to the centre. The multicursal model has two or more paths with dead ends, which confuse and frustrate the maze-treader (Doob 5). The essential labyrinthine characteristic of both models 
is the path's circuitousness, its digressions, detours and delays. How a maze-walker copes with the complexity of the path determines whether the final outcome will be spiritual awareness or moral blindness. Billy Kwan's journey is analogous to the unicursal maze pattern of the single linear path to truth. Hamilton's path, on the other hand, is that of the multicursal maze, which involves making choices, making mistakes and gradually discovering the path to truth. Hamilton represents Percival or Gawain since his journey is one that has many paths that eventually lead to spiritual truth. Billy Kwan's journey, on the other hand is that of Galahad.

Frequent references in the novel alluding to Celtic mythology and Billy's role as the Good Knight further emphasise his role as Galahad on a mission to bring spiritual enlightenment to those around him. It may be argued that Billy's path is circuitous and that it follows the multicursal model, since he is influenced by many religious theories. Yet, although Billy pursues many religions I argue that essentially he remains Christian in spirit. He is the Theseus figure battling the corrupt world of Sukarno's Indonesia, urging his fellow Australians to make the spiritual journey necessary for the salvation of their souls.

Koch uses the Fisher King myth in the Grail quest in order to articulate Billy's spiritual journey. In Celtic and Christian legends, the Fisher King is a maimed and impotent king who rules over a sterile and empty wasteland. There are certain constant elements in both the Celtic and Christian myths of the quest for the Grail. Both incorporate within their structure the visit of a mortal hero to a supernatural world, the maimed king, the barren land, the extraordinary dangers faced by the quester, and the question that must be asked in order to heal the king and bring fertility back to the land (Matarasso 12-13). In the Christian myth of the Grail legend, the Fisher King becomes the keeper of the grail, and the knights go in search of this symbol of spiritual enlightenment. The Fisher King myth has established itself within the western literary canon $\underline{10}$. Certainly, T.S. Eliot used the myth in The Waste Land in order to evoke the spiritual emptiness of contemporary society. Similarly, I argue that Koch uses the Fisher King myth to give voice to his belief that postmodern society is in a spiritually decadent phase. Thus, because it embodies both the spiritual journey and the concept of the world as a spiritual wasteland, the Fisher King symbolism becomes for Koch the myth through which he can elucidate the sacred for contemporary society.

In The Year of Living Dangerously, the Christian symbolism of the Grail legend as a spiritual journey with its Celtic and Aryan origins of the myth of the divine king is symbolised 
through the figure of Sukarno - the spiritually maimed king who fails in his duty towards his people. That Sukarno is a god to some of his people is made evident through various references in the novel which link him to the Hindu god Vishnu and to Billy's early vision of Sukarno as the divine ruler who will free his people from poverty. Billy believes that Sukarno, as “the Main Bearer of the People's Suffering" (YLD 12), will take on the role of the divine king and sing his country into being. In Hindu mythology, the god Vishnu is the creator, and by linking Sukarno with Vishnu, Koch gives him the role of creator and preserver of the Indonesian people. The other metaphors which allude to Sukarno's divine status are the myths of his sexual potency, which is signified in the novel through the phallic symbol of the tugu, and which relates to rituals of fertility associated with the vegetation deity. Sukarno's role as a vegetation deity, as a divine or semi-divine ruler upon whom the fertility of the land and the wealth of the people are dependent, is signified through his status as the "father of the farmers", the Marhaen (YLD 13). It is his concept of Marhaenism, of looking after the interests of the poor farmers, which Billy believes will deliver the people out of poverty. Sukarno's charismatic appeal weaves a veil of illusion, and his people treat him as a god who will deliver them from their oppressors.

In the myth of the Fisher King, there is a close connection between the spiritual health of the king and the land, and the sickness of the king is reflected back on to the land. The narrative structure of The Year of Living Dangerously mimics the idea that corruption or weakness in the King will lay the land to waste by depicting Sukarno as a dying king, who has lost his divine vision for his people: "The Wayang, like the city's bazaars and embassies, is full of rumours of the little dictator's impending death. One kidney is gone, and the other is said to be failing; if the stone shifts he will die. But he shows no sign of dying, indestructibly ranting at his rallies, and maintaining his sexual myth" (YLD 54). The king has become a puppet or a shadow of his former divine self; the mask he constructs of Indonesia's wealth, through buildings and monuments, only attests to his corruption, and like the ruler, the country itself is dying: "Monuments rose, topped by ecstatically gesturing figures like ghosts from the Third Reich, or Stalin's Russia. Borrowed millions were spent to construct a mask, while old Batavia's arteries hardened and its vital organs ceased to function" (YLD 28).

The metaphor of the dying king is linked to images of imprisonment and poverty. Sukarno's Indonesia is presented as a labyrinthine city of warrens and underground tunnels, devoid of electricity, water or drainage: "Behind the outward face of old Jakarta there is a second, 
secret city. It consists of warrens of earth-floored houses of cane and thatch, and of crazy shanties made from flattened oil cans and cardboard, spreading like a bacterial growth along the canals" (YLD 125). Other surreal images of the city are depicted through the metaphor of the betjak riders: "Betjaks, with their straining riders, toil like giant cockroaches at the muddy edges of the roads, or shelter under trees from the sheets of rain" (YLD 54). The surreal, wasteland images of Sukarno's kingdom reinforce the idea of a maimed and wounded king whose illness is linked to the underworld imagery of the slum poverty in Jakarta: "Flares, flares everywhere, in the flatland darkness, where garbled villas with orange-tiled roofs hid behind crumbling walls, and a dark, drain-like canal moved with evil slowness" (YLD 19-20). The "dark, drain-like canal" becomes a metaphor for disease, and the underworld imagery of warrens, caves and labyrinths depicts the suffering and malaise of a people whose king has betrayed them. The description in the text is of a poverty that spreads like a cancer, with beggars, cripples and women with malnourished babies vying for the tourists' attention. Sukarno's Indonesia of poverty, hatred, and chaos has the bizarre, carnival atmosphere of a world on the brink of disaster. Nowhere is the suffering and the demoralisation of the people captured more graphically than in the scene at the Kebayoran cemetery, where prostitutes sell their bodies "for the equivalent of twelve cents" a night to wealthy foreigners (YLD 180). These prostitutes also serve as the sirens or the temptresses in the Grail legend who attempt to lure the knights from their spiritual journey.

Koch manipulates the Fisher King myth in order to reinforce the idea of a sterile and barren wasteland in urgent need of a Christian knight to ask the question that will restore the vitality of the land and its people. Billy's rhetorical question to Hamilton, "What then must we do?"addresses through Christian concepts of compassion and caring the spiritual malaise of the Australian journalists confronted with the poverty of the Indonesian people. (YLD 21). Billy lives according to the Tolstoyian view of life, affirming his Christian duty by helping the Indonesians, and ignoring the derision of his fellow Australians. He is depicted as a character who searches for the truth in other religions, but whose moral conscience remains Christian in outlook. Billy's Christian humanism is beyond doubt ${ }_{11}$. His dossier on Ibu depicts him as Christ taking on the sins of the people; it is his Christian duty that results in his alienation from his fellow Australians and his derangement.

Billy's difference, which is emphasised through his dwarf physique and his Christian sense of duty, sets him apart from the other journalists. The clown figure ridiculed by the journalist 
thus portrays Billy as a Christ-like figure who sacrifices himself for his beliefs. His spiritual beliefs lead to his death, brought on himself by his confrontation with Sukarno's security guards. In the novel Koch veers between Christian and Hindu beliefs. Billy's Christian humanism exemplifies the Christian concept of love and free-will. But this is juxtaposed with the Hindu belief in determinism which is portrayed through the capricious dance of the goddess Kali, and the Hindu concept of salvation based on Krishna's doctrine of Karma Yoga and destiny $\underline{12}$. In the novel, Kali's dance takes on sinister overtones, and Billy's Christian humanism is depicted as futile in a land where the dance of Kali reigns. Kali's amorality and the Christian concept of a just and compassionate god are parallel themes in the novel.

Koch interweaves the myth of the Fisher King with Christian and Hindu myths by portraying Billy in the dual role of the quester after the truth and the divine king who takes on the suffering of the people. In other words, he takes over the role assigned by him to Sukarno, by becoming the "Main Bearer of the People's Suffering" (YLD 12). In the novel, Billy's initial role is that of the Christian knight in search of the Holy Grail. He idolises Sukarno and projects onto him the role of Vishnu, the creator in Hindu mythology. When Sukarno fails in his duty, Billy changes roles. He is no longer the knight, but Krishna, the Hindu god of love, who sets himself the task of redeeming Hamilton's soul. Billy assigns himself the role of Krishna - he becomes the charioteer of Hamilton's soul - a role that is articulated through the symbolism of the wayang puppets. The inherent instability in Billy's role as both Christian humanist and Krishna's advocate becomes evident when he fails to pursue the path of detachment. Billy's increasing concern for the poor identifies him as a man who can not detach himself from the suffering he sees in Indonesia; his passion and desire ultimately leading to his destruction.

In the YLD, Billy's denunciation of Hamilton's lack of compassion for the prostitutes highlights that it is not the defilement of the body, but the degeneracy of a desacrilised society that is no longer concerned with the spiritual, and with the consequent Christian values of love, caring and compassion that saddens Billy (59). It is a world where violence and pornography reflect the "torments of a degenerate psyche", with society itself becoming increasingly like the "waiting-room of Hell" (YLD 236). This concept of a society devoid of compassion and love, a society where the absence of the sacred leads to the suppression of the spirit and the abuse of the body is also evident in Janette Turner Hospital's The Last Magician, through its graphic depiction of an underworld of physical and sexual abuse 
endured by the child-prostitutes, drug addicts and the marginalised. In The Kadaitcha Sung, Sam Watson also uses graphic images of violence, brutality and sexual abuse of the Aborigines by Europeans to put forward the concept that, in their pursuit of material wealth, the Europeans have lost their spiritual souls.

Billy's charity towards the poor, and his willingness to challenge society's complacency illustrate that he functions as the divine king and the scapegoat within the novel. According to Hindu philosophy, to carry out one's dharma, one's duty, one has to become a true seeker of the self within, that is, one must detach one's ego from worldly concerns. Billy is not the true seeker of the self in the Hindu sense because he is unable to detach his ego from the suffering of the people. The doctrine of detachment therefore stresses that the Self, the divine substance within each individual, should not allow itself to become entangled with the web of desire, which is the sensual aspect of the material world. Unlike the other characters, Billy is unable to ignore the poverty that surrounds him. He follows his moral conscience by doing what he can to alleviate the afflictions of the people. He confronts the indifference of those around him by taking photographs of Glodok, the Chinese section of Old Jakarta, that depict the poverty of the "kampong people" (YLD 80). Billy's response to queries about why he takes these photographs demonstrates his spiritual belief that one has a moral duty to act in accordance with one's beliefs: “"Those pictures up there tell a story about the people here that you don't tell in your reports - that no one's telling, [...] Who really cares about those people - bathing in sewage, scrounging for rice and a few pieces of vegetables and meat, for one meal a day?"' (YLD 81). Koch juxtaposes Hindu and Christian philosophy to show that there are no real answers for the metaphysical questions of being and existence. Billy's moral conscience spurs him on to action, but the Hindu philosophy of detachment permeating the narrative highlights that, like the other journalists, he is trapped within the world of desire. He is, according to Krishna's philosophy of detachment, caught in the web of illusion and desire: he has become involved with the suffering of the Indonesian people. His alienating and irrational behaviour towards the other journalists is indicative of one who has crossed the Rubicon into the realm of madness.

That desire is the enemy of the soul is the advice Billy fails to apply to his own salvation. His actions towards the end of the novel illustrate that he is caught in the web of desire: of violent passion, anger, bewilderment, and confusion. He becomes increasingly irrational, and his diary entries vilify Sukarno with greater and greater intensity. Billy condemns Sukarno 
because he has become a tyrant, a Herod who sacrifices his people and their children for material wealth and power. Sukarno is shown to be entrapped within the illusory world of wealth and power and as such he represents a fallen god. Sukarno fails to live up to his ideal of supporting the farmer, which were embodied in his concept of Marhaenism. As a ruler who had great visions for his country, he fails in his spiritual duty to nurture his people, and this betrayal by Sukarno reverberates in Billy's plea: “A kilo of rice now costs a worker's daily wage. Your people suffer Sukarno! Marhaen suffers! How can you bear his suffering?" (YLD 134).

The image of a country on the brink of destruction, Billy's delusions and the mayhem that follows Sukarno's loss of power, together express the Hindu philosophy of the dangers of illusion and the wheel of destiny. This is conveyed through the imagery of the goddess Kali, whose dance represents the destiny of life, alerting the reader to the Hindu metaphor of the wheel of life, signifying that the Indonesians are trapped within the cycle of suffering and poverty; the destiny of life from which their divine king Sukarno is unable to release them.

It is the contradictions between the Hindu and Christian concepts of duty that spurs the novel's actions. Billy finds Krishna's philosophy of detachment impossible to follow since he is unable to separate his ego from the sufferings of those around him. However, he is still carrying out his dharma, in the Hindu sense of not giving up the activity to which one is born. When Billy goes to the Hotel Indonesia, it is to confront Sukarno, to plead with him, as the guardian of the people, to feed them: "Sukarno, Feed Your People" (YLD 249). This can be interpreted as an endorsement, by the author, of the Hindu and Christian doctrines of salvation, one which is affected through the spiritual symbolism of food $\underline{13}$. Because it governs all processes by sustaining and providing nourishment, food is seen as the divine principle existing in the universe, and the life-giving and life-destroying symbolism of food in Brahmanical philosophy has become associated with the divine being who exists in everything. Food as embodying the spiritual life force is also evident in the Christian myth of the Grail legend where the symbolism of the Grail is associated with the body of Christ, and with the chalice that Jesus drank from at the Last Supper. By portraying Sukarno as a divinity who has failed in his spiritual and material duty Koch appears to fuse the Vedic symbolism of food with the Eucharistic symbol of Christ as the divine king who provides spiritual nourishment for his followers. Billy's eloquent plea: "Sukarno, Feed Your People”, becomes a message condemning a ruler who, in accepting the role of leader of his people, has failed in 
his duty: the people are starving, the water is polluted and everywhere there is sickness and death.

Billy's compassion for this suffering results in his death, and his death illustrates that Koch, for all his fascination with Manichaeanism, and Krishna's doctrine of duty, finds Hindu philosophy too alienating. By presenting Billy as a Christ-like figure who sacrifices himself for his beliefs, Koch rejects the amorality of the Hindu gods, favouring instead the Christian concept of a loving and forgiving god $\underline{14}$. Koch suggests the symbol of the crucified Christ reaching out to save his people, through the actions of Billy who reaches beyond his own being, who risks his life for values which he believes are important. Billy's death is the lacerating wound that leads to Hamilton's enlightenment and which provides the Australian journalists with an understanding of the strength of his spiritual beliefs.

By actively choosing the role of Christ, Billy repudiates the Hindu concept of a Divine being whose dance signifies both life and death, a divinity that is indifferent to the suffering of world. Kali becomes the negative Other of the divine symbol of Christ. The massacres and the civil war in Indonesia following Sukarno's defeat become a personification of the destructive dance of Kali. The Dionysiac energy unleashed by the combat between the Communist and Suharto's army result in massacres that call to mind the maenads of Greek mythology, as in the murder of the top Army generals by the women in the Communist force:

"Kill the capitalist bureaucrats!" Rifle butts and knives rise and fall; blood flows; the generals cry out. And the women, fiercer than the men, struggle to get closer, in the ecstasy of this unique night: they will torment the generals sexually, and then castrate them; they will cut out their eyes with razor blades. The blue lights watch, like evil spirits. (YLD 270)

The "frenzied" actions of the "Gerwani" take place on the night of a "full moon" a symbol associated with Hecate, but which is here associated with Kali, and this is reinforced in the narrator's retelling of the massacres following the communist insurgence:

Out there, at this deepest hour of night, Maha-Kali dances: she of many names, all of which mean Time. In circles of lanterns in the paddy fields at night, the cane-knives will chop and chop at figures tied to trees; and trucks will carry loads of human heads - all pleasing to the dancer at the cemetery. (YLD 293) 
Kali, the goddess who demands blood sacrifice, spreads a penumbra of evil over the landscape. In presenting the Dionysiac aspects of Kali, Koch is able to interrogate Hindu and Christian philosophy by asking moral questions which are meaningful for contemporary society.

Koch's characters escape from the labyrinthine world of Indonesia, but remain encapsulated within a mythical world. Hamilton and Jill make a journey back to the dawn of time: "Night's egg had cracked; outside the porthole was the sweet crystal ether of the north (YLD 294), but it is also "the night of ãkãsa: the dark which has no end" (YLD 292). The metaphors of light and darkness intervene, and one is left with the image of Kali's cosmic dance signifying the ceaseless interplay of life and death : "His good eye burned, and he closed it for a moment. As soon as he did so, a dark shape pedalled and creaked across his middle distance: a betjak, whose rider wore a black shirt, black shorts, and a limp straw hat, and the name of whose machine was Tengah Malam: midnight" (YLD 296).

Through its interrogation of Hindu and Christian philosophy, The Year of Living Dangerously provides a brief glimpse into the sacred space that is the other of the profane world. But it can not provide a transcendent reality because the contemporary character can no longer become immersed in a sacred mythical world; history and time intervene. All that remains is the world of the imagination, and it is this imaginary world which provides the brief escape from the profane space of mundane reality.

\section{Notes}

1 See Bk V111, Ovid's Metamorphosis, Penguin Classics: "Minos determined to rid his home of this shameful sight, by shutting the monster away in an enclosure of elaborate and involved design, where it could not been seen. Daedalus, an architect famous for his skill, constructed the maze, confusing the usual marks of direction, and leading the eye of the beholder astray by devious paths winding in different directions." Daedalus' artistry is elaborated in the design of the labyrinth: "Daedalus constructed countless wandering paths and was himself scarcely able to find his way back to the entrance, so confusing was the maze" (Trans. Innes p.183).

2 My ideas have been partly influenced by Penelope Doob's study of labyrinths in literature in The Idea of the Labyrinth from Classical Antiquity through the Middle Ages, which I have 
adapted for my interpretation of the conflicting worldviews of the sacred in the Year of Living Dangerously

$\underline{3}$ In Sanskrit Time is kãla and the word is very close to the name of the Great Goddess, Kãli. [...] Kãla also means black, darkened, stained. Time is black because it is irrational, hard, merciless. Those who live under the dominion of time are subject to every kind of suffering, and to be set free consists primarily in the abolition of time, in an escape from the law of change. (Eliade Patterns in Comparative Religion 182)

4 In Crossing the Gap, Koch remarks: She [Kali] was woman as the incarnation of time and flux and destiny: the Indian counterpart of the White Lady we have banished from our days, but who still haunts our sleep. She was one of those whom the Australian Aborigines have so memorably described as the Eternal Ones of the Dream. As Kali-Ferry across the Ocean of Existence, womb and tomb, protectress and destroyer, eternal dancer (9).

5 Felicia Campbell provides an erudite explanation of the wayang symbolism in "Silver Screen, Shadow Play: The Tradition of the Wayang Kulit in The Year of Living Dangerously": "The wayang or shadow play is presented in an environment where antiquity and the present blend into each other as the dalang both puppet master and shaman, sits on the ground manipulating up to 100 leather puppets before the large white screen" (163).

$\underline{6}$ A dalang, or puppeteer, relates a familiar story from the island's mythological past while manipulating flat leather puppets" (Brandon 1). To the Indonesians, the puppets of the wayang represent the gods and ancestors of their race: "These shadows were the original cause of the physical man, the eternal patterns after which he is built" (Moebirman 5), a concept analogous to the Platonic theory of Forms.

7The Grail legend continues to have a pervasive influence on writers and poets; T.S. Eliot's poem The Waste Land being one that engages with the theme of spiritual decadence and the blight on the land. The Grail motif, as symbolising the archetypal search for truth, is also noted by Manju Jain: "the search for it became an archetypal symbol of the quest for spiritual truth, especially in medieval romances about King Arthur and his knights" (139).

$\underline{8}$ The La Queste del Saint Graal is an early-thirteenth-century romance that was influenced by Albert Pauphilet's Etudes sur la Quest del Saint Graal. Frederick Locke remarks that it 
was Pauphilet's romance that "provided the framework for all subsequent quest studies of the romance" (Preface).

9 In The Idea of the Labyrinth from Classical Antiquity through the Middle Ages, Penelope Doob suggests: "There is a grand maze-maker, a Daedalus, be he divine, diabolical, or human, and that maze-maker has so structured the work of art that its circuitous toils lead to a goal, good or ill, enlightening or destructive" (54).

10 Jessie Weston's interpretation of the origins of the Fisher King myth, in From Ritual to Romance (1957), is that the myth dates back to rituals associated with the Aryan myth of the divine king: "upon whose life, and unimpaired vitality, the existence of his land and people directly depends" (62).

11 I use the word Christian humanism to mean the Christian values of love and compassion which are combined with the humanistic values of the dignity of man. Humanism is by nature described as a more worldly and irreligious philosophy, but I endorse the view expressed by Peter Gay and R.K Webb in Modern Europe to 1815: "Petrarch underscored the religious compromise that most Humanists were to adopt: a continued unquestioning loyalty to the Christian faith coupled with a new understanding for the classics of pagans, especially Roman antiquity" (61).

12 In the Bhagavad Gita, Krishna's teaching to Arjuna is based on the philosophy of Karma Yoga. Karma Yoga is the doctrine of Selfless Action that stresses that the devotee must choose the middle path of life. It is a doctrine that shuns desire, power, and self-gratification. At the same time, Karma Yoga warns against inaction. One must do one's duty, but remain detached from the fruits of one's action (Zimmer 386).

13 In the Vedic Hymn of Food, Brahma, the transcendent power, makes manifest that food and the divine source are one, by saying: "I am the first-born of the divine essence.Before the gods sprang into existence, I was. I am the navel (the center and the source) of immortality. Whoever bestows me on others - thereby keeps me to himself. I am Food. I feed on food and its feeder. (Zimmer 345)

14 Zimmer provides lucid explanation of the difference between the Hindu and Christian concepts of God. In Hinduism, though Brahma "is himself perfect love, and inclined to all of his devotees, no matter what their plane of understanding, he is also, and at the same time, 
supremely indifferent, absolutely unconcerned; for he is himself possessed of no ego" (Zimmer 396). Brahma therefore is the extreme opposite of Christ who dies on the cross for the sins of the people as: "the scapegoat branded as a criminal, the Lamb that takes upon itself the sins of the world, relieves unclean mankind of its merited death by shedding his own precious blood; hanging on the cross as history's most conspicuous victim of judicial murder" (Zimmer 396). 